\title{
Progeny tested bull production for dairy cattle development in Bangladesh
}

\author{
AKFH Bhuiyan ${ }^{1}$, MM Rashid $^{2}$, RA Khan ${ }^{2}$, MA Habib ${ }^{3}$, MSA bhuiyan $^{1}$, MA Faiz ${ }^{2}$ \\ ${ }^{1}$ Department of Animal Breeding and Genetics, Bangladesh Agricultural University, Mymensingh 2202; ${ }^{2}$ Breed \\ Up-gradation Through Progeny Test Project, Department of Livestock Services, Farmgate, Dhaka 1215; \\ ${ }^{3}$ Bangladesh Livestock Research Institute, Savar, Dhaka 1341, Bangladesh
}

\begin{abstract}
The Department of Livestock Services has been implementing "Breed Up-gradation Through Progeny Test" Project since 2003, for selecting dairy breeding bulls based on their progeny performance. This paper describes the procedures followed for setting up field based progeny testing scheme involving private farmers and reports the data of progeny testing in Bangladesh from 2007 to 2013. Until now more than 5000 farmers, having at least one Friesian crossbred cow, were registered under this program in 22 districts of the country. Five Friesian crossbred candidate bulls were evaluated on their estimated breeding values for 100-day milk yields of 199 first calving daughters during 2007 to 2013. Out of five bulls, two bulls were found promising due to their positive breeding values compared to the others. By 2015, 100 day lactation milk yield data from more than 450 daughters of 6 candidate bulls (used in 2009) of the second batch are expected to be available for evaluation, and about 2452 daughters (heifers) of different ages produced out of 29 candidate bulls are available under field recording in different geographical areas of the country. So, proven dairy bull production through field-based progeny testing program in Bangladesh is underway.
\end{abstract}

Key words: Breeding value, Friesian crossbred, milk yield, proven bull, progeny test, candidate bull

Bangladesh Animal Husbandry Association. All rights reserved. Bang. J. Anim. Sci. 2015. 44 (2): 106-112

\section{Introduction}

The total livestock population of Bangladesh is composed of 23.30 million cattle, 25.20 million goats, 1.50 million buffalo and 3.10 million sheep (DLS 2013). The cattle population consists of Local (L), Friesian $x$ Local crossbred $(F \times L)$, Friesian $x$ Sahiwal crossbred $(F \times S L)$, Friesian $x$ Local $\times$ Sahiwal crossbred ( $F \times L \times S L)$ and Sahiwal $x$ Local crossbred (SL $\times$ L) cattle. Out of 6.9 million breedable cows and heifers, $F \times L$ crossbred contributes about $24 \%$ (Huque et al. 2011). The milk production performance of $F \times L$ crossbred cows under Bangladesh condition substantially improved (from 5 to 12 liters/day) gradually (linear) over the decades (Bhuiyan 2011).

Breeding bulls used in national Artificial Insemination ( $\mathrm{Al}$ ) program of Bangladesh were being selected since decades through assessing only the milk yield information of bull mothers kept at government farms. More than $80 \%$ of the breeding bulls used in government Al program are Friesian $x$ Local crossbred (DLS

2013). Therefore, the proportion of this genotype increased in the cattle population rapidly and there has already been some improvement in productivity per animal which contributed to long term growth in the dairy sector (Jabbar 2010; Bhuiyan 2011). And this has happened due to accumulation of milk producing genes in the genetic composition of the cattle population brought through the introduction of crossbreeding with exotic Friesian semen.

The genetic improvement is permanent in nature and accumulates generation after generation, thus this improvement is the real service to poor farmers. Since, relatively higher genetic progress is possible in a field-based progeny testing program compared to what is possible in other approaches, progeny testing is considered as the best tool for achieving higher genetic progress in any population. However, this process is time consuming and involves a lot of field activities 


\section{Progeny tested bull production}

described by Ghaffar et al. (2008). In India, Holstein Friesian, Holstein Friesian crossbred, Jersey crossbred, Sunandini cattle and Murrah and Mehsana buffalo bulls are being evaluated through field-based progeny testing programs (NDDB 2014).

Bangladesh has an annual need of 13.32 million tons (MT) of milk with a production amounting only 3.46 MT (Bangladesh Economic Review 2012). So, it is clear that still there is a huge shortage of milk for human consumption. As a step towards dairy development, government has undertaken "Breed Up-gradation Through Progeny Test" Project since 2003 targeting genetic improvement of the dairy cattle population of the country by ensuring production and use of Friesian $x$ Local progeny tested bulls with known dairy merit. The set goals were: (i) production of superior proven bulls and (ii) to organize and build capacity of contract farmers to produce proven bulls. Therefore, the objective of this study was to evaluate the procedures of aforesaid progeny tested dairy bull production system.

\section{Materials and Methods}

The first phase of the aforesaid field-based progeny test project was initiated by the Department of Livestock Services (DLS) in 2002 and its second phase came into operation in 2008. During the year 2007 to 2013, forty five FxL crossbred candidate bulls were identified and maintained at Central Cattle Breeding Station, were put under the field progeny testing program. Five bulls from first batch were evaluated and the rest will be evaluated step by step in the subsequent years. The following steps were undertaken for setting up field-based progeny testing scheme.

\section{Selection of area}

The Department of Livestock Services implemented national Al program extensively through 22 District Artificial Insemination Centers since 1975. Therefore, these 22 districts were selected for execution of progeny testing program for $F \times L$ crossbred bulls.

Table 1. District wise contract farmers and their registered daughters

\begin{tabular}{lcc}
\hline Name of district & Number of contract farmers & No. of daughters under recording \\
\hline Dhaka & 300 & 143 \\
Mymensingh & 300 & 213 \\
Tangail & 200 & 166 \\
Jamalpur & 250 & 175 \\
Comilla & 225 & 157 \\
Noakhali & 250 & 189 \\
Sylhet & 250 & 172 \\
Potuakhali & 200 & 68 \\
Barisal & 250 & 188 \\
Faridpur & 300 & 123 \\
Jessore & 300 & 193 \\
Khulna & 350 & 272 \\
Kustia & 300 & 199 \\
Pabna & 325 & 158 \\
Rajshahi & 300 & 121 \\
Bogra & 275 & 70 \\
Rangpur & 275 & 106 \\
Thakurgoan & 250 & 79 \\
Chittagong & 275 & 69 \\
Rangamati & 100 & 27 \\
Khagrachari & 100 & 10 \\
Bandarban & 100 & 11 \\
\hline & & \\
\hline & &
\end{tabular}




\section{Selection and training of farmers}

A standard and uniform operating procedure was developed for selecting the contract farmers included in this program. The main criterion of farmer selection was the enthusiasm, cooperation and willingness of the farmer to improve their crossbred cattle for milk production. Until today a total of 5475 contract farmers were identified by field staffs, later verified by scientific officers and then finally selected from the whole country. The selected farmers were then trained by the project on the steps and activities involved in progeny test program and simple but essential animal record keeping system (Table 1 ).

Selected farmers were given incentive in terms of money, free vaccination and de-worming agent for their cows and progeny.

\section{Training of personnel}

A total of 1024 government livestock officers and 279 field staffs were trained on the value, purpose and procedure of progeny testing program, recent tools and techniques of livestock development and scientific methods of animal data recording needed for successful implementation of a field-based progeny testing program.

\section{Organization of progeny show}

A total of 48 progeny shows were organized in district level in order to bring awareness among the private dairy farmers on the significance of producing bull calves of high dairy merit and to seek their cooperation for participating in animal recording system. The participated farmers were awarded with prizes on the basis of merit of their bull calves appeared in the show.

\section{Registration of animals}

The FXL crossbred heifers/cows of selected farmers was individually identified with neck belts and ear tags. The tags were printed with unique numbers. The production and reproduction status of heifers/cows was recorded in a register (called Herd Book) maintained in each farmers herd. These registered animals were randomly inseminated by the semen of candidate bulls for obtaining daughters.

\section{Candidate bull selection and semen dissemination}

Elite cows in different districts were inseminated with the semen of best available bulls to produce future bull calves. The bull calves born out of elite cows were kept with farmers up to the age of 1215 months. At this age the bull calves were selected as trial bulls considering their dam's lactation yield and purchased. The purchased trial bull calves were transferred to Central Cattle Breeding Station, Savar and reared under better feeding and management conditions. Later bull calves were selected as candidate bulls based on their growth, physical and breeding soundness, and freeness from diseases, testicular measurements and semen quality. A total of forty five $F \times L$ candidate bulls were finally selected out of 436 purchased trial bull calves collected from various areas of the country during 2006 to 2012. The average daily milk yield in $1^{\text {st }} 100$ days of lactation of bull mothers over the selection period is presented in Figure 1. Upon final selection of candidate bulls, 600 doses semen from each candidate bull were collected and disseminated into different districts for test $\mathrm{Al}$ with already registered $F \times L$ crossbred heifers/cows of the farmers. Out of 45 candidate bulls, 5 were discarded from the program due to broken leg, lack of libido and positive tuberculosis result.

\section{Field progeny data collection including milk recording}

All the progeny heifer calves born out of test Al were registered and identified by neck belt with a unique identification number. Data on date and weight at birth, age at puberty, date of artificial insemination and calving of heifers were taken during regular and timely visits to farmer's house. The most important activities of this program were the milk recording of individual daughter cows. Milk recording of every $1^{\text {st }}$ calving daughter of the candidate bulls from any district was carried out by data collectors under the strict guidance of Scientific Officers on part lactation test day basis.

Milk yield for 24 hours was recorded at $6^{\text {th }}, 21^{\text {st }}$, $36^{\text {th }}, 51^{\text {st }}, 66^{\text {th }}, 81^{\text {st }}$ and $96^{\text {th }}$ day of lactation and milk yield for $1^{\text {st }} 100$ days of lactation was calculated from these seven test day milk yield records by interpolation method approved by ICAR (2012). Hand milking at morning and afternoon was done and it was assumed that calf 


\section{Progeny tested bull production}

suckled required amount of milk from her mother. However, 100-day lactation milk yield data of 199 registered daughters distributed over 181 herds were used for genetic evaluation (Henderson, 1975) of 5 candidate bulls. In this study, candidate bulls were ranked according to their estimated breeding values (EBV) calculated using their daughters' $1^{\text {st }} 100$ day lactation milk yield with the computer program described below.

\section{Statistical analysis}

For genetic analyses, variance components and heritability of milk yield were estimated applying Restricted Maximum Likelihood (REML) approach by VCE 4.2.5 computer package (Groeneveld 1998). For REML analysis, single trait animal model was used considering geographical area, herd size and management level as fixed effects. The general animal model was of the form:

$\mathbf{Y}=\mathbf{X b}+\mathbf{Z a}+\mathbf{W} \mathbf{c}+\mathbf{e}$

Where, $Y=$ Vector of observations; $X, Z$ and $W=$ Known incidence matrices associated with levels of $b, a$ and $c$ with $Y ; b=$ Unknown vector of fixed effects (i.e. area, herd size and management); $a=$ Unknown vector of breeding values; $\mathrm{c}=$ Unknown vector of permanent environmental effects; $\mathrm{e}=$ Vector of residual effect.

For the prediction and estimation of breeding values, PEST 3.1 (Groeneveld et al. 1998) program was used following a single trait animal model considering animal as a random effect and geographical area, herd size and management level as fixed effects. The results of variance matrices from VCE 4.2.5 (Groeneveld 1998) were incorporated in the PEST program for breeding value estimation.

\section{Results and Discussion}

\section{Genetic evaluation of candidate bulls}

There were more than 5000 cows under registration at 22 districts. Until now 40 candidate bulls were set under progeny testing program and they were under different stages of evaluation. Out of these bulls, 5 bulls were evaluated through Best Linear Unbiased Prediction (BLUP) analysis, and estimated breeding values (EBV) of candidate bulls and average 100 days milk yield of their daughters are presented in Table 2. D-11 and JR-01 bulls (Photograph 1) were proved as positive on the basis of EVB $(+36.8$ and +26.1 liter, respectively). In contrast, the EBVs of bull IDs BDN-26, GP-03 and PN-39 were negative. Khan and Ghaffar (2007) reported similar results in buffalo bull progeny testing in Pakistan, and they revealed that out of 137 progeny tested buffalo bulls evaluated by Daughter-Dam Comparison, 68 bulls were declared as positive and 69 bulls were negative.

Table 2. Genetic evaluation results of candidate bulls

\begin{tabular}{|c|c|c|c|c|c|c|c|c|}
\hline $\begin{array}{l}\text { Bull } \\
\text { ID. }\end{array}$ & Dam genotype & $\begin{array}{l}\text { Sire ID. and } \\
\text { genotype }\end{array}$ & $\begin{array}{c}\text { No. of } \\
\text { daughter }\end{array}$ & $\begin{array}{l}\text { No. of } \\
\text { herd }\end{array}$ & $\begin{array}{l}\text { No. of } \\
\text { district }\end{array}$ & $\begin{array}{l}\text { A100-day } \\
\text { MY (liter) } \\
\text { Mean } \pm \text { SE }\end{array}$ & $\begin{array}{l}\text { EBV for } \\
\text { MY }\end{array}$ & $\begin{array}{c}\text { Rank } \\
\text { based on } \\
\text { EBV }\end{array}$ \\
\hline D-11 & $50 \% \mathrm{~F} \times 50 \% \mathrm{~L}$ & $\begin{array}{c}60 \\
\text { (100\% Friesian) }\end{array}$ & 31 & 28 & 5 & $1481 \pm 56.4$ & +36.8 & 1 \\
\hline JR-01 & $50 \% \mathrm{~F} \times 50 \% \mathrm{~L}$ & $\begin{array}{c}65 \\
\text { (100\% Friesian) }\end{array}$ & 61 & 54 & 6 & $1469 \pm 45.2$ & +26.1 & 2 \\
\hline GP-03 & $75 \% \mathrm{~F} \times 25 \% \mathrm{~L}$ & $\begin{array}{c}57 \\
\text { (100\% Friesian) }\end{array}$ & 37 & 32 & 4 & $1261 \pm 32.4$ & -2.37 & 3 \\
\hline $\begin{array}{l}\text { BDN- } \\
26\end{array}$ & $50 \% \mathrm{~F} \times 50 \% \mathrm{~L}$ & $\begin{array}{c}6087 \\
(87.5 \% \mathrm{~F} \mathrm{x} \\
12.5 \% \mathrm{~L})\end{array}$ & 35 & 33 & 6 & $1306 \pm 33.5$ & -12.0 & 4 \\
\hline PN-39 & $50 \% \mathrm{~F} \times 50 \% \mathrm{~L}$ & $\begin{array}{c}6087 \\
(87.5 \% \mathrm{~F} x \\
12.5 \% \mathrm{~L})\end{array}$ & 35 & 34 & 4 & $1275 \pm 36.8$ & -63.5 & 5 \\
\hline
\end{tabular}

$I D .=$ Identification, $A 100 \mathrm{dMY}=$ Average 100-days milk yield of progeny, $E B V=$ Estimated breeding value 
Photograph 1. EBV positive bulls

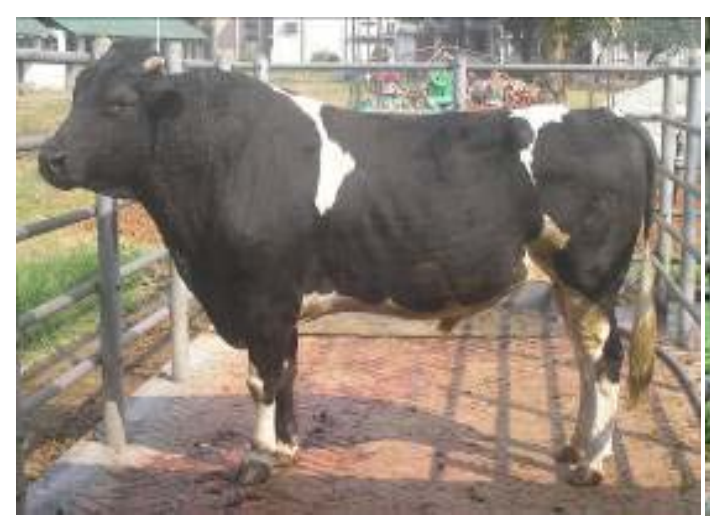

Bull ID: D-11

The milk yield for $1^{\text {st }} 100$-days of $1^{\text {st }}$ calving daughters was 1481, 1469, 1261, 1306 and 1275 liters, respectively for bull IDs D-11, JR01, GP-03, BDN-26 and PN-39. Two positive candidate bulls, D-11 and JR-01, had 92 daughters altogether. The 100 days milk yield of their daughters was $1473 \pm 35.3$ liters whereas the 100 days milk yield for 107 daughters of 3 negative candidate bulls averaged at $1281 \pm 19.7$ liters. Overall difference of milk yield in two groups of daughters was 192 liters.

The estimated heritability $\left(\mathrm{h}^{2}\right)$ for 100 day milk yield was found to be $0.49 \pm 0.04$. The estimate could be considered reliable because of its small standard error value. Similar heritability value (0.49) was found by Pander et al. (1992) in British Holstein Friesian. The heritability estimate for milk yield in present study was slightly higher than the estimate for Friesian $x$ Sahiwal $(0.46 \pm 0.18)$ found by Gaur et al. (1999) and for some exotic breeds $(0.45 \pm 0.03)$ reported by Hossen et al. (2012). Ageeb and Hillers (1991) reported $h^{2}$ of lactation yield as $0.68 \pm 0.30$ for Friesian crossbreds. However, medium estimates of $\mathrm{h}^{2}$ of milk yield were reported by Schopen et al. (2009) in Dutch

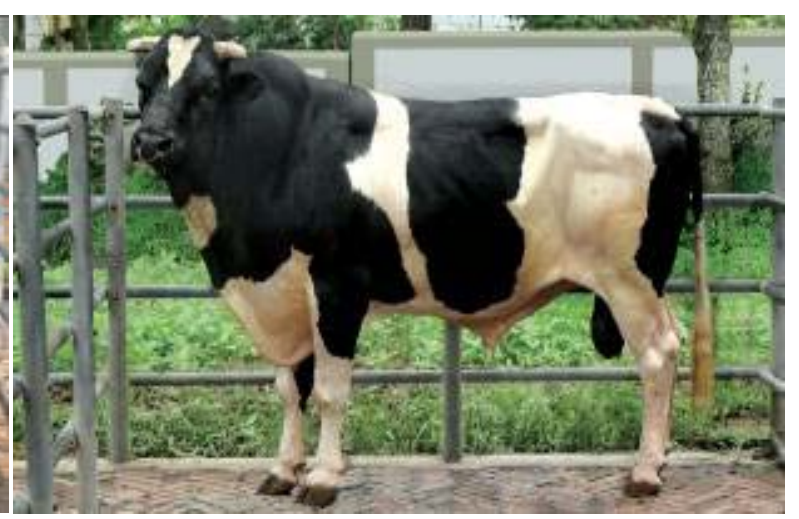

Bull ID: J R-01

Holstein-Friesians (0.41), Dev et al. (2008) in native cattle (0.40), I latsia et al. (2007) in Sahiwal cattle (0.28-0.46) and Jakobsen et al. (2002) in Danish Holsteins (0.41). The variation in $h^{2}$ values between present study and those referred above could mainly be due to genotype of cows and the sample sizes.

Out of aforementioned 5 proven bulls, only bull ID JR-01 was available in Central Cattle Breeding Station during final evaluation. Therefore, JR-01 was declared as "The $1^{\text {st }}$ Proven Bull" in Bangladesh by the Ministry of Fisheries and Livestock through a National Seminar in June 2013 and a proven bull catalogue was published. On the basis of evaluation results, semen of this proven bull was being used to inseminate elite cows for the future production of candidate bull calves for the field-based progeny testing program to continue.

\section{Evaluation of candidate bulls in future}

Recording data on a total of 2909 daughters (heifers) born to date in different geographical areas of the country with the semen of 35 candidate bulls are in progress (Table 3 ). Milk yield data of more than 450

Table 3. Candidate bulls waiting for genetic evaluation

\begin{tabular}{llccc}
\hline $\begin{array}{c}\text { Year of } \\
\text { testing }\end{array}$ & \multicolumn{1}{c}{ Bull I D. } & $\begin{array}{c}\text { No. of } \\
\text { bull }\end{array}$ & $\begin{array}{c}\text { Daughters } \\
\text { under } \\
\text { recording }\end{array}$ & $\begin{array}{c}\text { Expected year } \\
\text { of genetic } \\
\text { evaluation }\end{array}$ \\
\hline 2009 & $\mathrm{KH}-14, \mathrm{KH}-04, \mathrm{KH}-19, \mathrm{TH}-104, \mathrm{TH}-107, \mathrm{RJ}-14$ & 6 & 457 & 2015 \\
010 & $\begin{array}{l}801,802,202,821,822,01,14,837,850, \\
835,840,852\end{array}$ & 12 & 1036 & 2016 \\
2011 & $301,804,204,305,405,407,843,402$ & 8 & 548 & 2017 \\
2012 & $80,313,345,502,503,609,610,606,93$ & 9 & 868 & 2018 \\
\hline
\end{tabular}




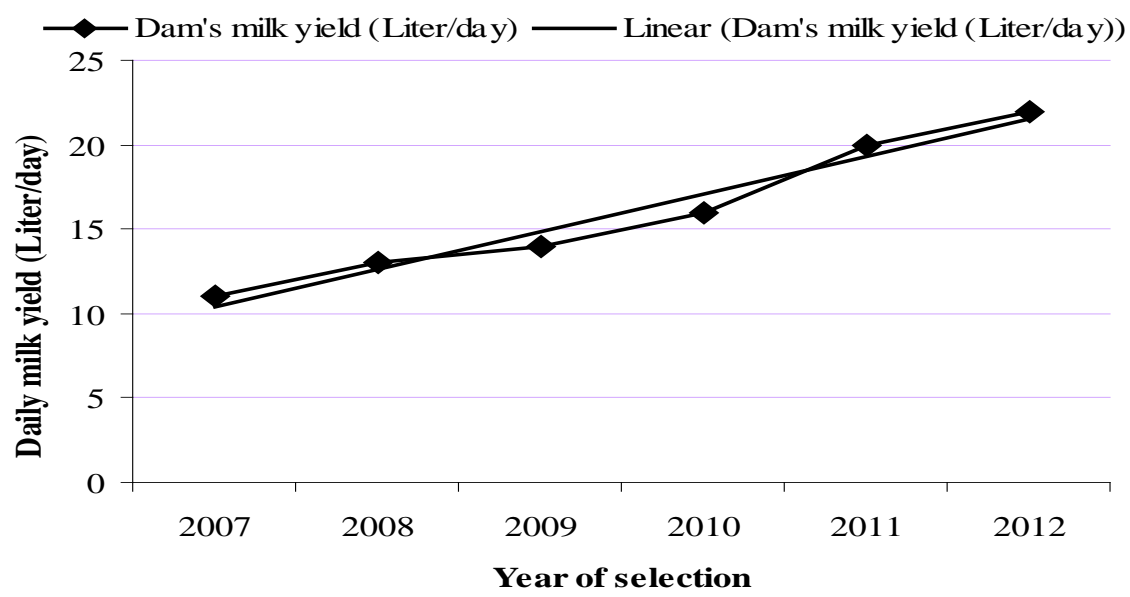

Figure 1. Average daily milk yield in $1^{\text {st }} 100$ days of dams of candidate bulls

daughters from 6 candidate bulls (used in 2009) of the second batch will be available by the end of 2015 for evaluation. Accordingly in the subsequent years, a good number of candidate bulls would be possible to evaluate (Table 3 ).

About $90 \%$ of the milk produced to date was sold to local consumers, vendors and sweetmeat makers. Further, progeny testing scheme was started primarily giving more emphasis on milk quantity rather than milk fat and protein yield. During the recent past years, formal milk processors have been growing faster in Bangladesh, collecting more than 10\% of total milk from the community based dairy farmers and selling processed milk and milk products to the urban consumers (Uddin et al. 2011). Farmers are rewarded by the processors according to milk fat yield and not by the volume of milk and protein yield. It is therefore essential for the progeny testing scheme to incorporate milk fat yield trait along with milk volume in the selection criteria to evaluate progeny tested breeding bulls.

\section{Conclusion}

After taking first endeavor for field-based cattle progeny testing by the Department of Livestock Services in 2002-2003, the $1^{\text {st }}$ batch of candidate bulls was progeny tested and one bull was declared as the $1^{\text {st }}$ Proven Bull in Bangladesh by the Ministry of Fisheries and Livestock in June 2013. Progeny tested bulls for dairy development in the country are in progress to add proven bull in dairy cattle industry and milk fat yield will be incorporated in the testing scheme along with milk volume.

\section{Acknowledgement}

The authors are highly thankful to the Department of Livestock Services (DLS), Ministry of Fisheries and Livestock for providing field data and necessary information regarding field-based progeny testing to make this study possible.

\section{References}

Ageeb AG, Hillers JK (1991). Effects of crossing local Sudanese cattle with British Friesian on performance traits. Bulletin of Animal Health and Production in Africa, 39: 69-76.

Bangladesh Economic Review (2012). Economic Division, Ministry of Finance. The Government of the People's Republic of Bangladesh, from http://www.mof.gov.bd

Bhuiyan AKFH (2011). Progeny Tested Seed Bull Production: Progress towards National Dairy Development. Keynote paper presented at the $3^{\text {rd }}$ National Seminar of Breed Up-gradation through Progeny Test Project held on 15 June 2011 at BIAM, Dhaka.

Deb GK, Mufti MM, Mostari MP, Huque KS (2008). Genetic evaluation of Bangladesh Livestock Research Institute Cattle Breed-1: Heritability and genetic correlation. Bangladesh Journal of Animal Science, 37(2): 2533. 
Department of Livestock Services (DLS) (2013). Annual report. Ministry of Fisheries and Livestock, from http://www.mofl.gov.bd

Gaur GK, Tripathi VN, Mukherjee S, Choudhary VK (1999). Indirect selection for genetic advancement in Frieswal cows. Indian Journal of Animal Science, 69: 263-265.

Ghaffar A, Khan MS, Raza SH, Afzal M (2008). Genetic improvement of indigenous dairy animals through progeny testing program. Pakistan Journal of Agricultural Science, 45(2): 410-412.

Groeneveld E (1998). VCE4.2.5 User's Guide and Reference Manual Version 1.1, Institute of Animal Husbandry and Animal Behavior. Mariensee, Federal Agricultural Research Center, Germany.

Groeneveld E, Kovac M, Wang T (1998). Multivariate Prediction and Estimation (PEST), Version 3.1. Department of Animal Sciences, University of Illinois.

Henderson, CR (1975). Use of all relatives in intraherd prediction of breeding values and producing abilities. Journal of Dairy Science, 58: 1910-1916.

Hossen MS, Husain SS, Bhuiyan AKFH, Hoque MA, Talukder MAS (2012). Sire evaluation of milk producers' cooperative union limited of Bangladesh. Bangladesh Journal of Animal Science, 41(2): 74-78.

Huque KS, Dev GK, Jalil MA (2011). High yielding dairy breed development in Bangladesh- limitations and opportunities. Paper presented in international workshop on "High yielding dairy breed development in Bangladesh" held at Bangladesh Livestock Research Institute, Dhaka from 28-29 September.

ICAR (2012). International Committee for Animal Recording. ICAR rules, standards and guidelines for recording milk and milk constituents. from http://www.icar.org/documents/Rules and regulations/Guidelines/Guidelines 2012.pdf
Ilatsia ED, Muasya TK, Muhuyi WB, Kahi AK (2007). Genetic and phenotypic parameters for test day milk yield of Sahiwal cattle in the semi-arid tropics. Animal, 1(2): 185-92.

Jabbar MA (2010). Policy barriers for dairy value chain development in Bangladesh with a focus on the north west region. A study for strengthening the dairy value chain in Bangladesh project of CARE Bangladesh, Dhaka.

Jakobsen JH, Madsen P, Jensen J, Pedersen J, Christensen LG, Sorensen DA (2002). Genetic parameters for milk production and persistency for Danish Holsteins estimated in random regression models using REML. Journal of Dairy Science, 85: 1607-1616.

Khan MA, Ghaffar A (2007). Recent advances in Progeny testing program for Nili Ravi buffalo in Pakistan. Italian Journal of Animal Science, 6(2): 381-384.

National Dairy Development Board (NDDB) (2014). Bull production. from http://www.nddb.coop/English/Services $\angle A B /$ Pages/Bull-Production.aspx

Pander BL, Hill WG, Thompson R (1992). Genetic parameters to test day records of British Holstein Friesian heifers. Animal Production, 55: 11-21.

Schopen GC, Heck JM, Bovenhuis H, Visker MH, van Valenberg $\mathrm{HJ}$, van Arendonk JA (2008). Genetic parameters for major milk proteins in Dutch HolsteinFriesians. Journal of Dairy Science, 92(3): 1182-91.

Uddin MM, Sultana MN, Ndambi OA, Alqaisi O, Hemme T, Peters KJ (2011). Milk production trends and dairy development in Bangladesh. Outlook on AGRI CULTURE, 40(3): 263-271. 